\title{
GENDER IMBALANCE IN NEW ZEALAND'S SENIOR LEGAL POSITIONS
}

\author{
Amelia Guy-Meakin*
}

Despite New Zealand's real progress toward gender equality over the past century, women remain under-represented in the country's senior legal positions. Disparities between men and women are not unique to the legal profession. They are particularly problematic, however, given that the law aims to pursue justice, and equal opportunity should be its paramount concern. This article examines some of the obstacles and constraints women face in attaining leadership roles in the New Zealand legal profession. Preliminary solutions to remedy these obstacles and constraints are proposed, including a necessary recognition that many female professionals offer distinct experiences and have different needs to their male counterparts.

In the late 19th century, New Zealand inherited a homogenous British legal system, which was the preserve of men from middle and elite classes. ${ }^{1}$ Despite massive gains in gender equality over the past century in New Zealand, women remain under-represented in the senior positions of the legal profession, including as partners, in judicial appointments and tenured faculty positions. ${ }^{2}$ Gender inequalities thus still present a challenge for women law graduates, and will continue to do so in the immediate future, given that they are not assuming leadership roles in proportion to their graduating numbers. This is seemingly endemic of a subtle - though shifting - bias erected against women in New Zealand, ${ }^{3}$ which impedes women's achievement of a reasonable work/life balance, constrains legal workplaces' creative solutions to the issue, and upholds gendered norms and stereotypes in favour of men and to the detriment of women in the legal profession.

* Co-winner of the 2013 Harriette Vine Essay Competition. LLB/BA (Hons). The author would like to thank the Wellington Women Lawyers Association, Victoria University of Wellington Law School and Associate Professor Elisabeth McDonald for facilitating the Competition.

1 Peter Spiller "The Courts and the Judiciary" in Peter Spiller, Jeremy Finn and Richard Boast (ed) A Legal History of New Zealand (Auckland University Press, Auckland, 2011) 187 at 208.

2 Human Rights Commission New Zealand Census of Women's Participation 2012 (Wellington, November 2012). Figures for 2012 showed 42.5 per cent of male barristers and solicitors were partners or directors. The figure for women was 15.9 per cent where they totalled 42.4 per cent of all practising barristers and solicitors in New Zealand.

3 Janet November "A woman's place is ... on the bench" (1993) 23 VUWLR 85 at 94. 
The shortage of senior ranking women is not unique to the legal profession as it is similarly apparent in business and political posts. ${ }^{4}$ Yet, the disparities between men and women in the legal profession are particularly troubling given that the law is supposed to pursue justice, and equal opportunity should be its paramount concern. ${ }^{5}$ As expressed by New Zealand Judge Carolyn Henwood, "the face of justice should show people coming from all types of backgrounds". 6

The law should not be confined to men's life experiences, which is commonly the reality. Such a phenomenon is perhaps attributable to an existing perception in New Zealand that gender equality has been achieved. This is a fiction conceivably derived from the fact that New Zealand was a world leader in gender equality, having been the first independent nation to grant women's suffrage. ${ }^{7}$ It appears men buy in to this fiction more than women. In 2014, the Gender and Diversity Research Group found that the majority ( 86 per cent) of women it surveyed indicated there were barriers to their progression in law firms as compared to approximately half (53 per cent) of the men. ${ }^{8}$ The divide in opinion shows real barriers exist to women's legal career progression. It may also show that certain women (and men) uphold existing barriers to legal career progression by perceiving those barriers into reality - and reassuring their endurance.

Evidence shows women law graduates' progression in the legal profession is restricted by their family responsibilities - as it is difficult for them to combine career and family. ${ }^{9}$ The legal profession demands long and inflexible hours. ${ }^{10}$ Clients expect total availability and immediate responses as a consequence of legal professionals now having 24/7 email and phone access. ${ }^{11}$ In addition, women lawyers cannot complete the "extras" that would facilitate their career advancement because of their clashing commitment to their families. This includes publishing articles, making presentations at meetings, participating in professional associations and basic

4 Susan Glazebrook "Looking through the Glass: Gender Inequality at the Senior Levels of New Zealand's Legal Profession" (paper presented to Chapman Tripp - Women in Law, Wellington, 16 September 2010) at 5.

5 Elena Kagan "Women and the Legal Profession: a status report" (Leslie H Arps Memorial Lecture, Yale University, New Haven, 2003) at 42.

6 November, above $\mathrm{n} 3$, at 103 .

7 Susan Glazebrook "Gender Equality in the Workforce: a Work in Progress" (paper presented to the Annual Professional Women's Dinner, Christchurch, 2009) at 1.

8 Gender and Diversity Research Group Women's Career Progression in Auckland Law Firms: Views from the top, views from the bottom (AUT University for the Auckland Women Lawyers' Association, 2014) at 8.

9 Janet November "'The Law as a Profession for Women': A Century of Progress? A Reply to Mary Jane Mossman" (2010) 33 AFLJ 161 at 170.

10 Glazebrook, above $\mathrm{n} 4$, at 6 .

11 Gender and Diversity Research Group, above n 8, at 13. 
networking. ${ }^{12}$ The impossible expectation of equating success with "going the extra mile" in the legal profession is compounded further for solo parents, who are mostly women. ${ }^{13}$ The problem is complex, and it cannot be resolved by women lawyers - and, in particular, solo mothers - working part time or on the "boundaries" of law to meet their families' needs ${ }^{14}$ as this could in turn question their commitment to their firm or the judiciary.

Women lawyers' brief withdrawals from the legal profession to meet their children's needs problematically result in their male counterparts moving ahead in their careers at their expense. Currently, when women return to the legal profession after withdrawals from it, there is a belief that motherhood distracts them. This finding is supported by research confirming that women lawyers receive poorer evaluations after returning from parental leave than at any other point in their careers. ${ }^{15}$ The "no concessions" culture entrenched in aspects of New Zealand's legal profession compounds women's perception that there is a forced choice between obtaining a senior legal position and childbearing. ${ }^{16}$ It is particularly startling given that children are a fact of life that should be catered to. ${ }^{17}$ New Zealand law firms, such as Chapman Tripp, have attempted to adapt to women's presence in the legal profession, rolling out inclusive leadership programmes. ${ }^{18}$ Yet, the very existence of these programmes in 2013 and 2014 indicates the slow evolution of the legal profession. Women law graduates still face the unfair challenge of navigating through its inflexibility, albeit to a lesser extent than previously. ${ }^{19}$

In addition, women law graduates often face the discriminatory assumption of the legal profession that childbearing is an innate desire of theirs. This assumption fails to take into account that women, like men, make life choices independently of their gender - and some women will choose not to have children. In this way, the legal profession arguably upholds essentialist understandings of gender based on biological difference, resisting demands by Third Wave feminists to let women define their gender independently of each other and men. ${ }^{20}$ Despite writing

12 American Bar Association Commission of Women in the Profession "Charting Our Progress: the Status of Women in the Profession Today" (2006) at 6 <www.americanbar.org>.

13 Amy Mansfield "The Battle of the Hats" New Zealand Lawyer (online ed, Auckland, 4 April 2008).

14 November, above n 3, at 170.

15 Research by the Project for Attorney Retention cited in Glazebrook, above n 4, at 5.

16 Gender and Diversity Research Group, above n 8, at 9.

17 Gill Gatfield Without Prejudice: Women in the Law (Brookers, Wellington, 1996) at 205.

18 Chapman Tripp "Australasian Award for Best Gender Diversity Initiative" (press release, 20 August 2013).

19 November, above n 9, at 171.

20 Susan James "Feminisms" in Terence Ball and Richard Bellamy (eds) The Cambridge History of Twentieth Century Political Thought (Cambridge University Press, Cambridge, 2003) at 513. 
in the 1990s, Gill Gatfield's research remains shamefully applicable in this respect. Gatfield established that the New Zealand legal profession - including firms and judiciaries - was reluctant to progress women at the same rate as men because of the perception that they will at some stage have children. ${ }^{21}$ A study by Statistics New Zealand reinforces Gatfield's evidence, finding that five years after completing their qualifications, male incomes were higher than those of females - within and outside the legal profession. ${ }^{22}$

Another related impediment to the progression of women law graduates in the legal profession is the differing perceptions of men and women in society. There exists a harmful "propagation of normative ideologies" that are supposedly inherent traits of men and women. ${ }^{23}$ Men are often associated with the traits of leadership and competitiveness, while women are associated with concerns for community and the compassionate treatment of others. ${ }^{24}$ Male characteristics are generally accepted as being necessary to the "business model" of the large law firms. ${ }^{25}$ For Justice Susan Glazebrook, leadership skills and masculinity are presumed inseparable in society since men have dominated leadership roles throughout history. ${ }^{26}$ It follows that society views femininity and competency as being at odds with one another, and women lawyers' self-doubt in contrast to their male counterparts as a consequence. ${ }^{27}$

If society's normative ideologies are subscribed to, it is especially damaging for women law graduates. This is because the concept of power, which is often assigned to men, has become disconnected from the goal of improving our society. This restricts women's ability to operate in the legal profession's leadership roles. Instead, the burden falls on women law graduates to "prove themselves" in a legal profession constructed by males; ${ }^{28}$ a "system that has been developed essentially without them". ${ }^{29}$

21 Gatfield, above $\mathrm{n} 17$, at 215.

22 Statistics New Zealand "Males have Higher Debt and Income" (press release, 18 December 2008).

23 Glazebrook, above $\mathrm{n}$ 7, at 12 .

24 AH Eagly and L Carli "Women and the Labyrinth of Leadership" (2007) 85 Harvard Business Review 62 at 66

25 Gender and Diversity Research Group, above n 8, at 8.

26 Glazebrook, above $\mathrm{n} 4$, at 7.

27 Kagan, above n 5, at 40.

28 November, above $\mathrm{n} 3$, at 100 .

29 CM Durham "Gender Equality in the Courts: Women's Work is Never Done" (1989) 57 Fordham LR 981 at 981. 
Women law graduates are at times harmfully encouraged to adopt masculine characteristics to achieve success. ${ }^{30}$ This arguably discourages diversity in the legal profession because women essentially become men, self-perpetuating a patriarchal legal system. Many liberal feminists have sought equality in the public realm, but have not changed that public realm structurally to ensure women law graduates can best participate in the legal profession. ${ }^{31}$ The liberal feminist model, while making some necessary gains, is thus deficient as it has shut out women from the legal profession who are unwilling to join the "old boys club". ${ }^{32}$ Moreover, liberal feminist legal professionals are rarely realistic role models for younger women law graduates given that many, though certainly not all, have succeeded in the profession by not marrying or having families. ${ }^{33}$ If it is to be believed that "the prior generation had to make sacrifices that the next generation of women simply does not want to make", ${ }^{34}$ then the legal profession's future senior positions are worryingly doomed to perpetual homogeneity. ${ }^{35}$

A further challenge facing women law graduates is that they have fewer networks and role models to encourage and promote their interests, as distinct from the large number of male networks and role models available to men. A report conducted in the United States indicated that men alienate women from their networks as they often view them as ill-equipped to generate business. ${ }^{36}$ The report's findings arguably apply to the New Zealand context as a number of clients openly or discreetly prefer to deal with men. ${ }^{37}$ In addition, conversation and activities involved in networking in New Zealand still tend to "male" interests, such as sporting events. ${ }^{38}$

To secure greater future representation of women law graduates in the senior positions of the legal profession, the deficiencies raised have to be addressed. One recommendation is to ensure that a woman's successful legal career is compatible with family responsibilities, requiring inflexible work environments to be made more flexible. This requires small changes that potentially have big implications. ${ }^{39}$ Justice Marion Anne Frater convincingly argues that "it shouldn't be necessary to

30 Glazebrook, above n 4, at 8.

31 James, above n 20, at 499.

32 Susan Glazebrook "It is just a matter of time and other myths" (paper presented to Get up and Speak 2013, Wellington, 2013) at 9.

33 American Bar Association Commission of Women in the Profession, above n 12, at 8.

34 At 8 .

35 Kagan, above n 5, at 42.

36 Glazebrook, above n 7, at 4 .

37 Gender and Diversity Research Group, above n 8, at 8.

38 At 8 .

39 Gender and Diversity Research Group, above n 8, at 58. 
conform with what is expected of men. It should be possible to accommodate different working arrangements and personal commitments. ${ }^{40}$ Instead of being judged by the long hours spent in a workplace, women (and men) should be held to objective standards that take into account the quality of their work. This may require a refashioning of the billable hours model that the legal profession follows. ${ }^{41}$

Legal professionals should additionally be able to take leave and work part time without biasing their status in a firm or on a judiciary. ${ }^{42}$ Most women currently do not become a partner working part time. ${ }^{43}$ The ability to operate outside the workplace because of improved email and phone access should be viewed as an opportunity, not impediment, for women's career progression. To operate successfully within the workplace, childcare should be extended from being an individual issue, as presently, to an issue of the workplace. ${ }^{44}$

Furthermore, law schools across New Zealand could play a greater role in educating students against the gendered norms that essentialise men and women and pose a significant challenge to women law graduates. Courses that seem to traditionally attract female students - such as family law or youth justice - could be made mandatory for male students, and vice versa. This would promote greater understanding, foster linkages and build networks between the sexes that would survive post-graduation from law school. The different perspectives men and women can offer the legal profession as a result of their life experiences are important. ${ }^{45}$ This does not confuse the view that women will "bring a new humanity to bear on [legal and judicial] decision making", ${ }^{46}$ because the academic literature that presumes women's inherent peacefulness within their capacity for childbearing can be defective. ${ }^{47}$ Rather, it acknowledges women's life experiences are different from those of men. ${ }^{48}$ Justice Joan Dempsey Klein accurately asserts that "today there is a growing voice for the view that recognising differences is essential" to true gender equality. ${ }^{49}$

40 November, above $\mathrm{n} 3$, at 103 .

41 Glazebrook, above $\mathrm{n} 4$, at 4 .

42 Glazebrook, above n 32, at 18.

43 Gender and Diversity Research Group, above n 8, at 53.

44 At 10 .

45 Glazebrook, above n 4, at 9.

46 At 10.

47 Sahla Aroussi "Women, Peace, and Security: Moving beyond feminist pacifism" (PSA Annual Conference, University College London, London, 2009).

48 Glazebrook, above $\mathrm{n} 4$, at 9

49 Judge J Dempsey Klein "Women Justice: Does She View the Law Differently?" (1989) 26 Court Review 18 at 23 . 
Finally, a greater number of mentoring programmes could be offered and promoted to women law graduates in order for their networks in the legal profession to mirror those of males. ${ }^{50}$ Senior female mentors could act as role models and be examples of success for both women and men at university and in the formative years of their legal careers. ${ }^{51}$ Equally, it is foreseeable that where senior males mentor female law students and graduates, intergenerational dialogue could be had and guidance given as to how to achieve success in the legal profession. Cross-gender mentoring has the promise of quashing the perception that women are professionally different to men in every sense. It could also invite and secure the idea in women graduates and male partners that women are capable successors to senior positions in the legal profession.

In order for the New Zealand legal profession to ensure it retains the best legal minds, it must support women to fill senior legal positions, so that these no longer remain the preserve of men. This requires recognition that women often have different needs to their male counterparts. The current status quo is concerning not only for the women whose aspirations are being frustrated, but also for New Zealand society as a whole, whose leadership in gender equality is undermined by gender imbalance in senior legal positions. By ignoring the talents and contributions women offer the legal profession, Associate Justice of the Supreme Court of the United States Elena Kagan warns that "[w]hat we have [in New Zealand and other countries globally] is a kind of brain drain, and we are all the poorer for it." 52

50 Glazebrook, above n 32, at 8 .

51 Wellington Women Lawyers Association "Mentoring Programme" <wwla.org.nz/mentoring-programme>.

52 Kagan, above n 5 , at 40. 
